\title{
EFFECT OF PH AND SRT ON DENITRIFYING PHOSPHORUS REMOVAL IN A2N SEQUENCING BATCH REACTOR PROCESS
}

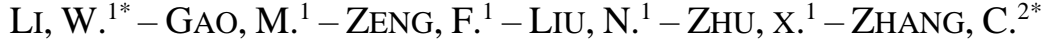 \\ ${ }^{1}$ School of Municipal and Environmental Engineering, Shenyang Jianzhu University \\ No.9, Hunnan East Road, Hunnan New District, Shenyang, China \\ ${ }^{2}$ School of Pharmaceutical Engineering, Shenyang Pharmaceutical University \\ Shenyang, China \\ ${ }^{*}$ Corresponding authors \\ e-mail: liweilengjinyue@163.com(Wei Li),twyla666@sina.com (Conglu Zhang) \\ (Received $11^{\text {th }}$ Jan 2019; accepted $8^{\text {th }}$ Mar 2019)
}

\begin{abstract}
This research investigates the effect of $\mathrm{pH}$ and sludge retention time (SRT) on denitrifying phosphorus removal. A series of experiments were conducted using two 20L sequencing batch units with the following configuration: anaerobic/anoxic and aerobic sequencing batch reactors (SBRs). It was found that variation in $\mathrm{pH}$ form 6.5 to 8 resulted in obvious increase in phosphorus release and uptake, organic matter degradation [measured by the chemical oxygen demand (COD) and the percentage volatile suspended solid (VSS)] and polyhydroxybutyrate (PHB) accumulation also showed a rising trend in the anaerobic period, but sludge acclimatized under $\mathrm{pH} 8.5$ condition exhibited a slightly lower denitrifying phosphorus removal capability. In addition, the rates of phosphorus release and uptake were 20.95 and $23.29 \mathrm{mg} / \mathrm{g}$ VSS / h in condition of $\mathrm{pH} 8$ value. Activated sludge with the SRT of 16 days possessed better nitrite nitrogen utilization, organic matter degradation and phosphorus removal than sludge with the SRT of 6,10 and 22 days, and polyphosphate concentration in anaerobic activated sludge per VSS decreased to $23.1 \mathrm{mg} / \mathrm{g}$ VSS, PHB concentration in anoxic activated sludge per VSS reduced to $16.3 \mathrm{mg} / \mathrm{g}$ VSS, thus, a dramatic denitrifying dephosphatation has occurred.
\end{abstract}

Keywords: phosphorus removal, organic matter degradation, sludge, $p H, S R T$

\section{Introduction}

In recent years, eutrophication caused by nitrogen and phosphorus pollution has attracted wide and intensive attention. Biological nutrient removal processes have been widely used in many municipal sewage treatment plants for several years (Wong et al., 2015). Conventional nitrogen and phosphorus removal were separately achieved by denitrifying bacteria and polyphosphate accumulating organisms (PAOs). Traditional biological nutrient removal processes have some problems between polyphosphate accumulating organism and denitrifying bacteria, such as external carbon source and sludge age. Kuba et al. (1993) reported that denitrifying polyphosphate accumulating organisms (DNPAOs) could achieve simultaneous nitrogen and phosphorus removal by using nitrate and/or nitrite as an electron donor. Denitrification and dephosphatation occur in sequencing batch reactor (SBR), which is different from continuous-flowactivated sludge system. DNPAOs have the similar metabolic characteristics to PAOs, degrade polyphosphate to orthophosphate and absorb organic compounds, are stored as polyhydroxyalkanoates (PHAs) in the cell under anaerobic condition. Under anoxic condition bacteria takes orthophosphate from liquid to synthesis polyphosphate with PHAs as electron donor and nitrate/nitrite as electron acceptor, meanwhile, achieves cell growth and maintance. Compared with traditional anaerobic/aerobic phosphorus removal, 
denitrifying phosphorus removal not only saves $50 \%$ organic carbon source and $30 \%$ energy consumption but also reduces $50 \%$ surplus sludge.

Nitrate as electron acceptor for denitrifying phosphorus removal has been recognized by scholars (Tayà et al., 2013; Wang et al., 2015a,b; Basset et al., 2016). However, in the early studies of biological nutrient removal processes, it was supposed that nitrite has been recognized as one of inhibitors in microbial metabolism (Zhou et al., 2011; Ge et al., 2016; Jabari et al., 2016). The nitrification reaction bath effluent may be not suitable for denitrifying phosphorus removal, it did not specially inoculate microorganisms with nitrite as electron acceptor under anoxic condition. Once up a time some people already realized that nitrite could also become electron acceptor of DNPAOs. Meinhold et al. (1999) showed that nitrite at low concentration levels $\left(4-5 \mathrm{mg}-\mathrm{NO}_{2}^{-}-\mathrm{N}\right)$ was not detrimental to anoxic phosphorus uptake and could serve as electron acceptor for anoxic phosphorus uptake. Introduce an phosphorus uptake ability of denitrifying polyphosphate accumulating bacteria, phosphorus uptake amount was over $30 \mathrm{mg} / \mathrm{L}$ by dosing $20 \mathrm{mg} / \mathrm{L}$ $\mathrm{NO}_{2}-\mathrm{N}$ in the SBR (Liu et al., 2014). According to the above literatures, different scholars gave the controversial conclusions of the nitrite influence on the biological anoxic phosphorus removal. It is necessary to evaluate adequately weather denitrifying phosphorus removal is efficiency and stability with nitrite as electron acceptor.

Although the $\mathrm{A}^{2} \mathrm{~N}$ process has the capacity of denitrifying dephosphatation, they differ in operational mode. The former operates in a single sludge system with nitrifiers and DPB mixed. In the $\mathrm{A}^{2} \mathrm{~N}$ processes, only DPB will be present. In this process, the minimum SRT for nitrifiers no longer dominates the minimum SRT for DPB (Bortone et al., 1994; Kuba et al., 1996a).

Denitrifying phosphorus removal using nitrite as electron acceptor has been considered difficult due to the lack of available control parameters. It is reported that $\mathrm{pH}$ and sludge retention time (SRT) are critical factors, which affect the performance of denitrification and dephosphatation of DNPAOs-nitrite.

The $\mathrm{pH}$ value of biological nutrient removal systems respond to cell membrane permeability and electric charge of microorganisms. Microbe growth and multiplication are closely related to the $\mathrm{pH}$ in the environment. Obviously, the suitable $\mathrm{pH}$ is crucial to ensure the dominant position of functional bacteria in the wastewater treatment processes. Many scholars studied the relationship between $\mathrm{pH}$ and biological phosphorus removal characteristics, it was found that the efficiency of anoxic phosphate uptake enhanced with the increase of pH for DNPAOs sludge. (Smolders et al., 1994; Sun et al., 2015; Liu et al., 2015). However, there is no publication investigated the mechanism of denitrifying polyphosphate accumulating organisms with nitrite as electron acceptor under different $\mathrm{pH}$ values till now.

Phosphorus in wastewater is removed by surplus sludge discharge, the effect of anoxic phosphorus removal could decrease if SRT is too high or too low. SRT not only reflects the growth environment and the generation period of microorganisms, what's more, it also influences the efficiency of nutrient removal, effluent quality and sludge yield in the biological nutrient removal processes. Impact of SRT on the biological phosphorus removal process has always been studying with PAOs in recent years (Ge et al., 2013, 2015). Liu et al. (2008) discovered that the optimal SRT was $15 \mathrm{~d}$ for polyphosphate accumulating organism with nitrate as electron acceptor in modified $\mathrm{A}^{2} \mathrm{~N}$ process. In accordance with a review of these literatures, it is found that few investigations have been conducted on the SRT influence on metabolic behavior of DNPAO with respect to anoxic phosphorus uptake using nitrites as electron acceptor. 
The purpose of this study is to study the correlation between $\mathrm{pH}$ and nutrient removal efficiency, seek a reliable sludge retention time (SRT) for achieving a high-level denitrifying phosphorus removal by using nitrite as electron acceptor, investigate the effect of $\mathrm{pH}$ and SRT on metabolic mechanism of DNPAO-nitrite, and also establish the control strategies for denitrifying phosphorus removal processes.

\section{Materials and methods}

\section{$A^{2} N-S B R$ system}

The tow-sludge $\mathrm{A}^{2} \mathrm{NSBR}$ process consisted of $\mathrm{A}^{2} \mathrm{SBR}$ reactor and NSBR reactor which were made from transparent plexiglass, were fed with synthetic wastewater and operated under anaerobic/anoxic/shortcut nitrifying condition separately. Anoxic denitrifying phosphorus uptake occurred in $\mathrm{A}^{2} \mathrm{SBR}$ reactor by using nitrite as electron acceptor from NSBR reactor effluent. NSBR reactor with a working volume of $3 \mathrm{~L}$, ran with two 4 h-cycles per day to realize shortcut nitrification by micro oxygen aeration, each cycle consisted of instantaneous feeding, $180 \mathrm{~min}$ aerobic reaction, $45 \mathrm{~min}$ settling and 15 min decanting. The sludge retention time (SRT) was 14 days, COD/N and $\mathrm{COD} / \mathrm{P}$ ratios were $0.2: 1$ and $23: 1$.

$\mathrm{A}^{2} \mathrm{SBR}$ reactor with a working volume of $10 \mathrm{~L}$ was inoculated with activated sludge from the secondary sedimentation tank of northern sewage treatment plant (Shenyang, China) and a laboratory-scale anaerobic-anoxic (A/A) reactor in which denitrifying polyphosphate accumulating organisms with nitrite electron acceptor were enriched. The denitrifying phosphorus removal reactor was conducted on $5.5 \mathrm{~h}$-cycle per day, operated with instantaneous feeding, $120 \mathrm{~min}$ anaerobic reaction, $150 \mathrm{~min}$ anoxic reaction, 45 min settling and 15 min drainage. All experiments were completed in the key laboratory of Liaoning university, China.

The operational critical factors of operation system were concluded as follow:

1) Effluent time of NSBR was consistent with anoxic phosphorus removal time of $\mathrm{A}^{2} \mathrm{SBR}, \mathrm{NO}_{2}^{-}-\mathrm{N}$ provided by shortcut nitrification could be completely utilized by denitrifying phosphorus removal as electron acceptor, realized coupling link of shortcut nitrification reactor and denitrifying phosphorus removal reactor.

2) Effluent $\mathrm{NO}_{2}{ }^{-}-\mathrm{N}$ concentration of NSBR met the need of anoxic phosphorus uptake and no interfering substance in the effluent flow was added to $\mathrm{A}^{2} \mathrm{SBR}$.

\section{Batch experiments}

Activated sludge taken from the anaerobic-anoxic SBR was subjected to effect of $\mathrm{pH}$ on denitrifying dephosphatation, the batch experiments were conducted after the SBR with circulating steadily and good performance. The performance of SBRs operation was that nitrite and nitrate concentration and nitrite accumulation rate in NSBR effluent were $92.6 \mathrm{mg} / \mathrm{L}, 5 \mathrm{mg} / \mathrm{L}$, and $94 \%$, the denitrifying phosphorus removal rate in $\mathrm{A}^{2} \mathrm{SBR}$ was $95 \%$. Amount of sewage was taken at the end of anoxic phase, and put in four 1-liter sealed glass bottles separately, domestic sewage was added to the glass as substrate. At different $\mathrm{pH}(6.5,7.5,8$ and 8.5), some batch tests were operated to understand the effect of $\mathrm{pH}$ on metabolism of denitrifying polyphosphate accumulating organisms very well. The operation mode of batch experiments was agreement with $\mathrm{A}^{2} \mathrm{SBR}$. The slurry mixture was stirred by magnetic stirring and mixed liquor suspended solid (MLSS) was $3300 \mathrm{mg} / \mathrm{L}$. In initial anaerobic reaction, nitrogen was injected into 
glass bottles to guarantee the anaerobic environment. In the anoxic phase nitrite and nitrate solution was continuously added into glass bottles as electron acceptor, and the concentrations of nitrite and nitrate could refer to $\mathrm{A}^{2} \mathrm{SBR}$, which were $21.7 \mathrm{mg} / \mathrm{L}$ $1.4 \mathrm{mg} / \mathrm{L}$.

The $\mathrm{pH}$ was controlled by using $\mathrm{pH}$ detection probe, acid pump and alkali pump. The other reaction conditions, such as temperature, DO and stirring speed were the same as SBR reactor.

The nutrient removal efficiency was stable, and the average denitrifying dephosphatation was above $90 \%$, effluent $\mathrm{TN}$ and $\mathrm{P}$ from the process can satisfy the GB effluent standards ( $\mathrm{P} 0.5 \mathrm{mg} / \mathrm{L}$ and $\mathrm{TN} 3 \mathrm{mg} / \mathrm{L}$ ), when the $\mathrm{A}^{2} \mathrm{~N}-\mathrm{SBR}$ ran to $80^{\text {th }}$ day. $\mathrm{A}^{2} \mathrm{SBR}$ sludge was designed to study the denitrifying phosphorus removal performance without sludge discharge and effect of SBR (6d, 10d, 16d and 22d) on nutrients removal. Surplus Sludge discharged was $0.5 \mathrm{~L}, 0.5 \mathrm{~L}, 0.5 \mathrm{~L}$, and $0.5 \mathrm{~L}$, respectively. COD, TP, $\mathrm{NO}_{2}^{-}-\mathrm{N}, \mathrm{NO}_{3}^{-}-\mathrm{N}, \mathrm{PHB}$, poly-P, MLSS, MLVSS were detected.

\section{Synthetic wastewater}

Synthetic wastewater was used in the experiment, the feed contained sodium acetate as carbon sources, $\mathrm{KH}_{2} \mathrm{PO}_{4}$ was used as phosphorus source, $\mathrm{NH}_{4} \mathrm{Cl}$ was added to provide nitrogen source, additionally, the other components also included $\mathrm{MgSO}_{4} 7 \mathrm{H}_{2} \mathrm{O}$, $\mathrm{CaCl}_{2}, \mathrm{NaHCO}_{3}$, and trace elements. Characteristics of synthetic domestic sewage were NSBR influent: CODcr 20.2 27.5 mg/L, $\mathrm{NH}_{4}{ }^{+}-\mathrm{N}$ 92.5 $103 \mathrm{mg} / \mathrm{L}, \mathrm{TN} 93 \sim 105.1$ $\mathrm{mg} / \mathrm{L}$, TP $0.8 \sim 1.2 \mathrm{mg} / \mathrm{L}, \mathrm{pH} 7 \sim 7.5$; $\mathrm{A}^{2} \mathrm{SBR}$ influent: CODcr $141 \sim 158.7 \mathrm{mg} / \mathrm{L} \mathrm{NH}_{4}{ }^{+}-$ $\mathrm{N} 1.0 \sim 3.0 \mathrm{mg} / \mathrm{L}, \mathrm{TN} 1.6 \sim 4.0 \mathrm{mg} / \mathrm{L}, \mathrm{TP} 7.8 \sim 13 \mathrm{mg} / \mathrm{L}, \mathrm{pH} 7.5 \sim 8$.

\section{Analytical methods}

COD, TP, $\mathrm{NO}_{2}^{-}-\mathrm{N}$, MLSS and MLVSS were analyzed in accordance with standard methods, and were measured according to the Chinese State Environmental Protection Agency Standard Methods (Chinese SEPA, 2002). The $\mathrm{pH}$ value and dissolved oxygen (DO) were measured online using $\mathrm{pH}$ and meters (DO530 and PH160, sinomeasure company, China), respectively. Glycogen was calculated according to Zhang et al. (2015). Biomass PHB content was detected by capillary-gas chromatography according to Cavaillé et al. (2013). GC working condition: A gas Perkin-Elmer gas chromatograph, equipped with a DB-5 column $(30 \mathrm{~m} \times 0.25 \mathrm{~mm} \times 0.25 \mu \mathrm{m})$, and fitted with a flame ionization detector,1:20 split, high purity nitrogen gas as carrier, 1:20 injection mode, sample volume $3 \mu \mathrm{l}$, furnace temperature $100^{\circ} \mathrm{C}$. Biomass sample preparation: Added 2 to 3 drops of formaldehyde to sewage samples to inhibit the biochemical reaction, centrifuged and removed the supernatant, then washed with phosphate buffer solution, after centrifugation, the sewage samples were moved into ampere tube and then dried with a freeze dryer and stored in frozen tube seal at $4{ }^{\circ} \mathrm{C}$ temperature. Esterification: The $50 \mathrm{mg}$ dried sewage was placed in $10 \mathrm{~mL}$ glass tube, mixed with equal volumes of 1-propanol / $\mathrm{HCl}$ and dichloroethane, added $1 \mathrm{mg}$ benzoic acid as internal standard substance. Benzoic acid as internal standard substance was added to mixture, heated in $100^{\circ} \mathrm{C}$ for 2 hours. After esterification, the samples were left to be cooled at room temperature and distilled water was added to $5 \mathrm{ml}$, shocked and solution for 10 minutes for effective extraction of potential residual-free organic acid, mixed with $\mathrm{Na}_{2} \mathrm{SO}_{4}$ to remove water and stored with gas chromatography automatic sampling bottle at $4^{\circ} \mathrm{C}$ temperature. 


\section{Results and discussion}

\section{Effect of $\mathrm{pH}$}

\section{Effect of $\mathrm{pH}$ on phosphorus concentration}

$\mathrm{pH}$ is an important parameter for denitrifying phosphorus removal process, could affect the enzymes activity of denitrifying polyphosphate accumulating organisms, because it is related to the change of cell membrane charge (Nittami et al., 2011). The competition between glycogen accumulating organism and polyphosphate accumulating organism could lead to a decrease of phosphorus removal rate in inappropriate $\mathrm{pH}$ environment.

The effect of various $\mathrm{pH}$ values on anaerobic and anoxic transformations of TP concentration and efficiency was investigated (Figure 1). The phosphorus specific release rate and uptake rate, expressed as net amount of phosphorus release and uptake per unit amount of VSS per hour in reactor (mg phosphorus/g VSS/ hour). It can be seen from Figure 1 that the anaerobic phosphate release increased from $27.52 \mathrm{mg} / \mathrm{L}$ to $42.69 \mathrm{mg} / \mathrm{L}$ when $\mathrm{pH}$ increased from 6.5 to 8 .

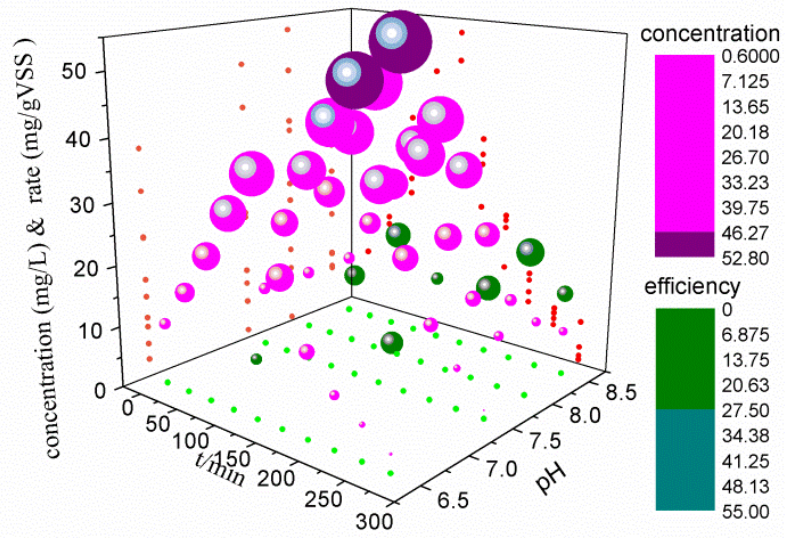

Figure 1. Effect of pH on phosphorus concentration and release and uptake rate

The scatter graph of phosphorus maximum specific anaerobic release rate showed upward trend with $\mathrm{pH}$ up to 8 , but a plateau appeared to be reached $20.95 \mathrm{mg} / \mathrm{g} \mathrm{VSS} / \mathrm{h}$ at this value. The result was coincided well with previous investigation, in which it was assumed that acetic acid absorption need proton motive force, which need adenosine triphosphate (ATP) formed by polyphosphate degradation. Higher $\mathrm{pH}$ value could reduce proton motive force and more phosphate release (Zhao et al., 2016; Reza et al., 2016; Lu et al., 2016). However, when $\mathrm{pH}$ value increased to 8.5, anaerobic phosphorus release decreased to $28.69 \mathrm{mg} / \mathrm{L}$. The phosphorus maximum specific anaerobic release rate began to decrease and reached $10.59 \mathrm{mg} / \mathrm{g} \mathrm{VSS} / \mathrm{h}$ in $\mathrm{pH} 8.5$. The main possible reason was the formation of chemical precipitation phosphate compounds. Some phosphorus precipitations were absorbed on the surface of bacteria, it hindered the absorption and release of phosphate by denitrifying polyphosphate accumulating organisms (Sun et al., 2015). Experimental results showed that anaerobic phosphorus release was the maximum under $\mathrm{pH}$ 8. The $\mathrm{pH}$ also influences anoxic phosphorus uptake when using $\mathrm{NO}_{2}^{-}-\mathrm{N}$ as electron acceptor, the concentration of effluent 
phosphorus reduced, and the rate of anoxic phosphorus uptake increased with $\mathrm{pH}$ increase during anoxic denitrifying phosphorus uptake. The amount of phosphorus uptake was $34.63 \mathrm{mg} / \mathrm{L}$, when $\mathrm{pH}$ was 6.5 . There was a remarkable downtrend, phosphorus concentration reached nearly $0 \mathrm{mg} / \mathrm{L}$ sharply, and anoxic phosphorus uptake reached $52.02 \mathrm{mg} / \mathrm{L}$ when $\mathrm{pH}$ was kept at 8 . When $\mathrm{pHs}$ were $6.5,7.5$ and 8 , the corresponding phosphorus specific uptake rates were $18.92,20.55$, and $23.29 \mathrm{mg} / \mathrm{g}$ $\mathrm{VSS} / \mathrm{h}$. The influence of $\mathrm{pH}$ on the specific uptake velocity was rather moderate (as in the case of net phosphorus production), except at the highest $\mathrm{pH} \mathrm{8.5,} \mathrm{at} \mathrm{which} \mathrm{the}$ specific uptake rate was reduced almost half of that calculated at $\mathrm{pH} 8$. Similar phenomena took place in anaerobic phosphorus release reaction, but the effect of $\mathrm{pH}$ value on phosphorus specific uptake rate was not greater than specific release rate. The reason was that a large number of polyhydroxybutyrate (PHB) were synthesized under higher $\mathrm{pH}$ condition, which provided electron donor for anoxic phosphorus uptake. The batch tests indicated $\mathrm{pH}$ was an important influencing factor of denitrifying phosphorus removal, the amount of phosphorus uptake was directly proportional to $\mathrm{pH}$ (between 6.5 and 8).

\section{Effect of pH on metabolic mechanism}

The anaerobic acetic acid absorption, PHB production, and polyphosphate degradation of active sludge from batch tests in different $\mathrm{pH}$ condition were illustrated in Figure 2. Clearly, the columnar diagrams of anaerobic acetic acid absorption, PHB synthesis and polyphosphate decomposition per unit amount of VSS in reactor showed rising trend by $\mathrm{pH}$ condition in the range of $6.5 \sim 8$. The rate of acetic acid absorption and PHB accumulation were $33.57 \mathrm{mg} / \mathrm{g} \mathrm{VSS} / \mathrm{h}$ and $20.73 \mathrm{mg} / \mathrm{g} \mathrm{VSS} / \mathrm{h}$, poly-P degradation percentage was $62.32 \%$ at $\mathrm{pH} 6.5$, and the rate of acetic acid absorption and PHB accumulation increased to $42.13 \mathrm{mg} / \mathrm{g} \mathrm{VSS} / \mathrm{h}$ and $31.43 \mathrm{mg} / \mathrm{g} \mathrm{VSS} / \mathrm{h}$, poly-P degradation percentage was $68.82 \%$ at $\mathrm{pH} 8$.

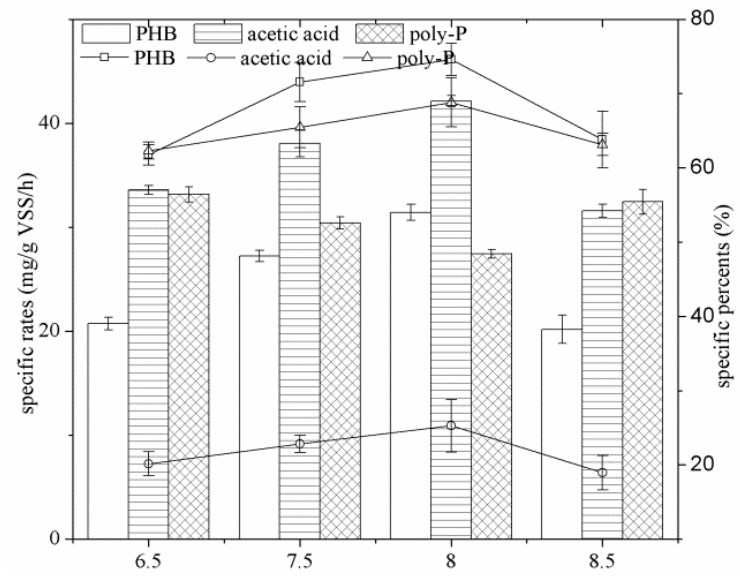

Figure 2. Specific rates and percents of PHB accumulation, acetic acid absorption and poly-P degradation

The trend curves of organic matter degradation, polyphosphate degradation rate and PHB conversion ratio along with $\mathrm{pH}$ value were the same as columnar diagrams. The main possible reason for different $\mathrm{pH}$ causing different $\mathrm{PHB}$ synthesis was related to 
potential difference caused by $\mathrm{pH}$ gradient. The greater potential difference was, the more phosphate was released and the more PHB was transformed (Wang et al., 2015). The $\mathrm{pH}$ was adjusted to 8 by addition $\mathrm{HCL}$ or $\mathrm{NaOH}$, it would be found that PHB conversion rate increased obviously, naturally acetic acid conversion rate and polyphosphate degradation ratio were also the largest. Thus increasing the anaerobic $\mathrm{pH}$ value would benefit to the microbial metabolism and phosphate removal. When $\mathrm{pH}$ was increased up to 8.5, because of chemical phosphorus precipitation, the rate of acetic acid absorption, PHB synthesis and poly-P degradation apparently decreased to $31.6 \mathrm{mg} / \mathrm{g}$ $\mathrm{VSS} / \mathrm{h}, 20.17 \mathrm{mg} / \mathrm{g} \mathrm{VSS} / \mathrm{h}$ and $32.44 \mathrm{mg} / \mathrm{g} \mathrm{VSS} / \mathrm{h}$. From the above considerations, it seems that $\mathrm{pH}$ should be strictly controlled below 8, it is the most favorable for biological denitrifying phosphorus removal.

The variation of COD, phosphorus, $\mathrm{NO}_{2}{ }^{-} \mathrm{N}, \mathrm{PHB}$ and polyphosphate concentration in stable anaerobic-anoxic SBR reactor at about $\mathrm{pH} 8$ was highlighted in Figure 3. In 2 hours anaerobic P-release phase, sludge polyphosphate content showed downward trend in 2 hours anaerobic P-release sludge, the poly-phosphorus decomposition was $33.52 \mathrm{mg} / \mathrm{g}$ VSS, PHB production was $62.87 \mathrm{mg} / \mathrm{g}$ VSS. It has been demonstrated that propionic acid enhances the accumulation of polyhydroxyalkanoates (PHB) in sludge, which could apply electron donor for the simultaneous denitritation and phosphorus removal in the presence of nitrite (Oehmen et al., 2005a,b, 2006; Kishida et al., 2006; Katsou et al., 2015).

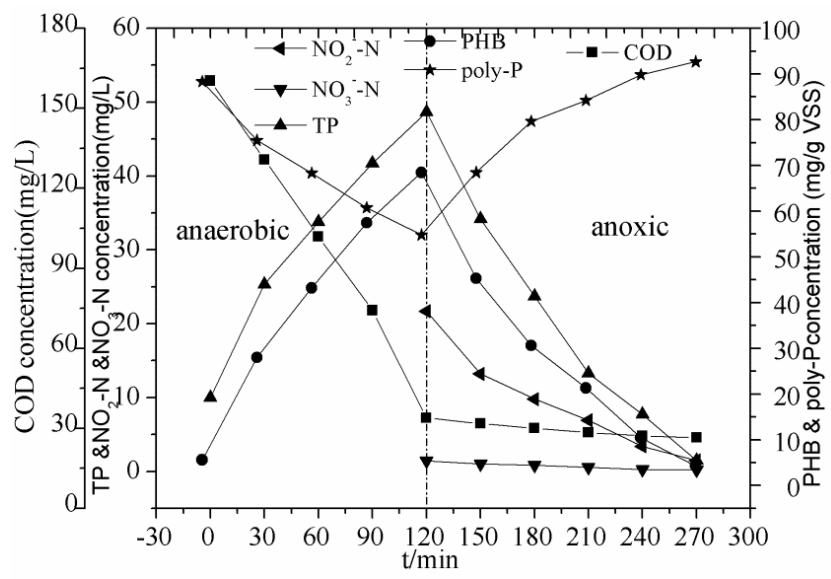

Figure 3. Variations of COD, TP, NO2--N, PHB and poly-P in typical cycle

Meanwhile COD concentration gradually decreased, and phosphate concentration increased to $48.98 \mathrm{mg} / \mathrm{L}$. The possible reason was that the higher energy demand for active uptake of acetic acid, which caused more polyphosphate degradation for producing more adenosine triphosphate (ATP) and resulted in more phosphorus release. In 2.5 hours anoxic P-uptake phase, sludge polyphosphate gradually accumulated to $92.67 \mathrm{mg} / \mathrm{g} \mathrm{VSS}$ at the end of reaction, meanwhile, there were steadily decrease in the curves of $\mathrm{PHB}, \mathrm{NO}_{2}^{-}-\mathrm{N}, \mathrm{NO}_{3}^{-}-\mathrm{N}$, and phosphorus, the concentrations of phosphate, $\mathrm{NO}_{2}^{-}-\mathrm{N}$ and $\mathrm{NO}_{3}^{-}-\mathrm{N}$ reached $1.47 \mathrm{mg} / \mathrm{L}, 1.5 \mathrm{mg} / \mathrm{L}$ and $0.21 \mathrm{mg} / \mathrm{L}$ in effluent. One explanation for this observation was that soluble orthophosphate (SOP) was absorbed and stored intracellular polyphosphate, which used PHB as electron acceptor and nitrite nitrogen as electron donor (Mielcarek et al., 2015). And additionally, the curve of COD concentration declined drastically in the anaerobic period, the curve of COD 
concentration declined more sharply in P-release than P- uptake, COD concentration was $33.93 \mathrm{mg} / \mathrm{L}$ in anaerobic effluent, and anaerobic COD removal rate sped up to $78.84 \%$. COD was removed mainly in anaerobic stage, which avoided the competition of traditional denitrification bacteria in anoxic stage. This experimental phenomenon was similar to the one of Liu et al. (2015). $22 \mathrm{mg} / \mathrm{L} \mathrm{NO}_{2}{ }^{-}-\mathrm{N}$ and $1.5 \mathrm{mg} / \mathrm{L} \mathrm{NO}_{3}{ }^{-} \mathrm{N}$ as electron acceptors were removed by denitrifying phosphorus removal organisms, meanwhile $47.21 \mathrm{mg} / \mathrm{L}$ phosphorus was removed. The injections concentration of $\mathrm{NO}_{2}^{-}-$ $\mathrm{N}$ and $\mathrm{NO}_{3}{ }^{-}-\mathrm{N}$ were consistent with the $\mathrm{A}^{2} \mathrm{SBR}$. It was shown that the majority of nitrite and nitrate were consumed by denitrifying phosphorus accumulating bacteria, but not by conventional denitrifying bacteria.

It is verified through batch experiment that $22 \mathrm{mg} / \mathrm{L}$ nitrite as the main electron acceptor has a good performance, these nitrite levels did not inhibit the DBPRN. It is completely suitable for applying to denitrifying phosphorus remove, and the results is quite similar to the $\mathrm{A}^{2} \mathrm{~N}-\mathrm{SBR}$ operation. Previous findings suggest that the nitrite levels at the end of the aerobic phase did not exceed $35 \mathrm{mg} \mathrm{L}$ and were usually in the range of $10 \sim 25 \mathrm{mg} / \mathrm{L}$. Plotting sPUR anoxic versus the initial nitrite concentration at the end of the aerobic phase for a specific experimental period (i.e. period V) did not show any activity inhibition (Katsou et al., 2015).

\section{Effect of SRT}

\section{Denitrifying phosphorus removal without sludge discharge}

The effects of denitrifying phosphorus removal were investigated under condition of 18 days operation without sludge discharge that could make sure the optimum sludge age range. With reactor running continuously without sludge discharge, the effect of phosphorus removal was not stable. Results depicted in Figure 4 indicated that phosphorus removal percentage fluctuated between $48 \%$ and $86.75 \%$.

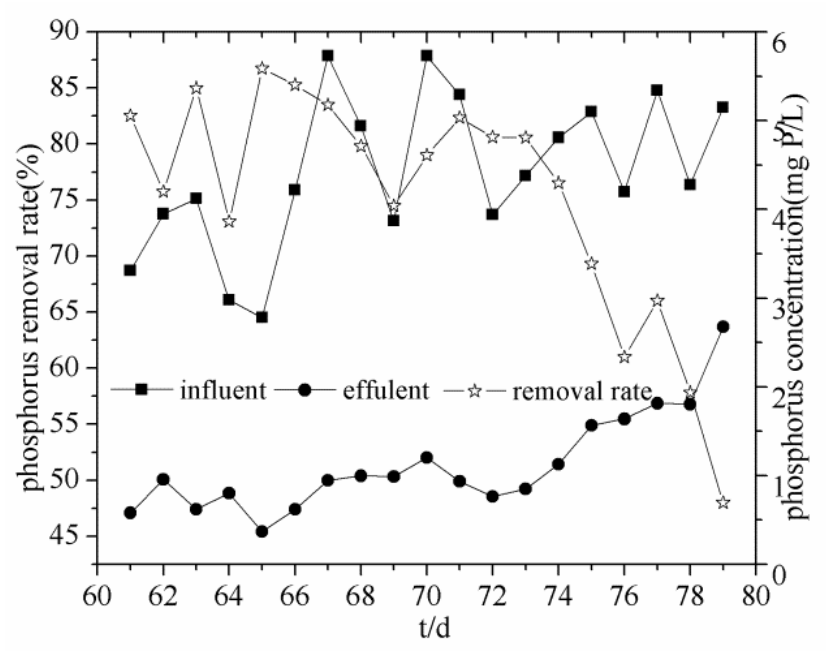

Figure 4. Performance of phosphorus removal of the system without sludge discharge

It was noted that the phosphorus concentration of the effluent was less than $3 \mathrm{mg} / \mathrm{L}$, the average percentage of phosphorus removal reached $80.67 \%$ at the 16 th day, over a period of 16 days, yield of phosphorus removal decreased gradually. It can be 
concluded that there was a phenomenon of denitrifying phosphorus removal in condition of no sludge discharge. However, the phosphorus removal efficiency began to decline after the reactor was operated for more than 16 days without surplus sludge discharge. This result was not consistent with traditional theory of phosphorus removal, which argued that the shorter sludge age, the higher phosphorus removal efficiency. While Hatamoto et al. (2015) obtained the same conclusions, they believed that denitrifying poly-phosphorus accumulating microorganisms (DPAO) grew slowly and resulted in a longer sludge age.

The anaerobic/anoxic SBR ran continuously over 18 days and without sludge discharge, and the effect of SRT on $\mathrm{NO}_{2}^{-}-\mathrm{N}$ and COD removal was shown in Figure 5. Unlike phosphorus, $\mathrm{COD}$ and $\mathrm{NO}_{2}^{-}-\mathrm{N}$ removal ratios were 84.02\% 92.71\% and $75.83 \% \sim 88.75 \%$ respectively, $\mathrm{COD}$ and $\mathrm{NO}_{2}^{-}-\mathrm{N}$ average discharge concentration were $22.91 \mathrm{mg} / \mathrm{L}$ and $2.01 \mathrm{mg} / \mathrm{L}$, implying that no excess sludge discharge would not instinct degradation of organic compounds, even if phosphorus bacteria decreased above 16 days' sludge age. The main reason is that organic compounds have been used as nutrients not only by denitrifying polyphosphate accumulating microorganisms but also other heterotrophic bacteria (Kuba et al., 1996b; Ge et al., 2015). Most of Nitrite nitrogen was absorbed as electron acceptor mainly by DPAO. Additionally, a small amount was removed by denitrification.

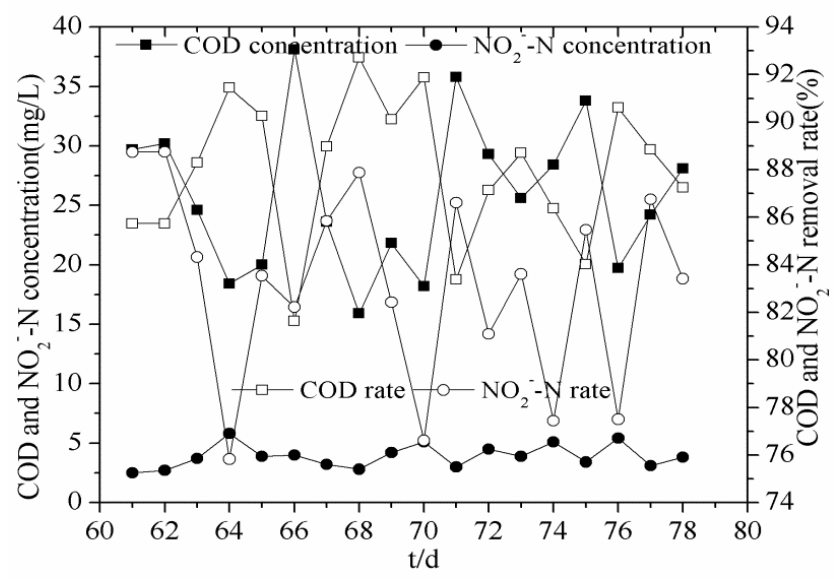

Figure 5. Performance of COD and NO2--N removal in the system without sludge discharge

\section{Effect of SRT on phosphorus removal}

Figure 6 showed the removal rate and content variation of phosphorus achieved by sludge at different sludge age $(6 \mathrm{~d}, 10 \mathrm{~d}, 16 \mathrm{~d}$ and $22 \mathrm{~d})$. It was indicated that the average phosphorus removal ratio was $61.32 \%$ and average phosphorus concentration in effluent was $7.78 \mathrm{mg} / \mathrm{L}$ in average, when the sludge age was 6 days. Since SRT is shorter than generation period of bacteria, lots of DPB sludge was discharged and SRT was too short to metabolize actively for denitrifying polyphosphate accumulating organisms, this made DPB become non dominant strains. In addition, short SRT led to high sludge organic loading and residual carbon source, which inhibited microbial physiological activity of denitrifying polyphosphate accumulating organisms and traditional denitrifying bacteria grew rapidly. When the SRT was increased from $6 \mathrm{~d}$ to $16 \mathrm{~d}$, the average denitrifying phosphorus removal ratio increased gradually and finally stabilized 
at about $93.12 \%$, with a decreased phosphorus effluent concentration of $0.69 \mathrm{mg} / \mathrm{L}$. This is not consistent with the traditional view that at the smaller SRT, the better effect of phosphorus removal. However, when SRT reached 22d, sewage treatment performance of SBR got worse and phosphorus removal ratio decreased to $60.27 \%$. The main reason is that the excessive sludge retention time resulted in reduction of organic load and ineffective phosphorus release (Luo et al., 2014). The literature suggests that denitrifying phosphorus removal sludge in strict anaerobic/anoxic systems showed the richest denitrifying phosphorus removal bacteria diversity when SRT were approximately $15-20 \mathrm{~d}$ (Lv et al., 2013). $\mathrm{A}^{2} \mathrm{~N}$ processes can accommodate denitrifying dephosphatation, in the range of SRT (15 20d), effluent $\mathrm{N}$ and $\mathrm{P}$ from the two processes can satisfy the EC effluent standards $\left(\mathrm{P}<1 \mathrm{~g} / \mathrm{m}^{3}\right.$ and $\left.\mathrm{N}<10 \mathrm{~g} / \mathrm{m}^{3}\right)$ (Hao et al., 2001). Other works have also shown that a sludge retention time of 15 16 days was favorable for denitrifying phosphorus removal (Zeng et al., 2002; Peng et al., 2004).

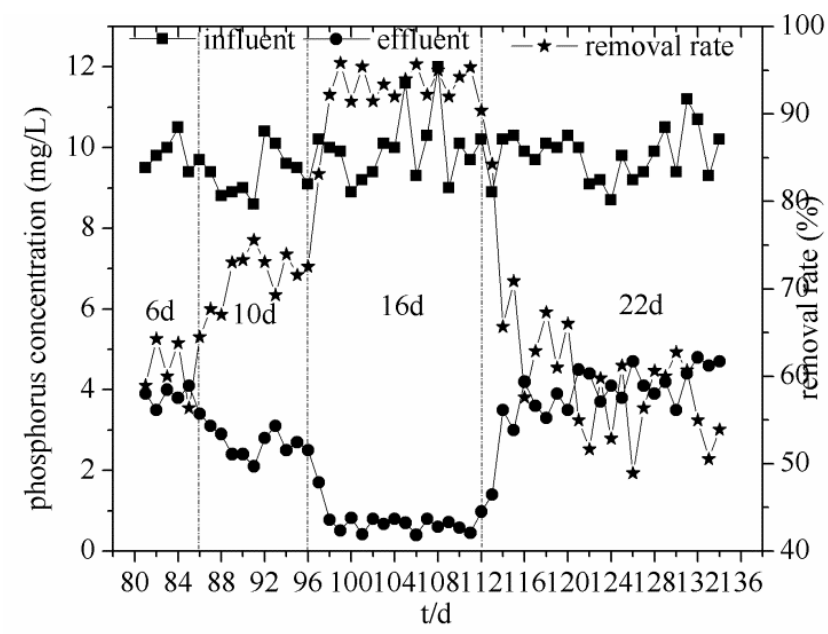

Figure 6. Effect of SRT on the performance of phosphorus removal

The anaerobic acetic acid degradation [measured by chemical oxygen demand (COD)] and PHB production were shown in Figure 7. It was found that activated sludge with an SRT of 16 days possessed better anaerobic acetic acid degradation and PHB production than other sludge time. The result was the same as the phosphorus variation. The average concentrations of COD and PHB in anaerobic effluent were $31.31 \mathrm{mg} / \mathrm{L}$ and $95.1 \mathrm{mg} / \mathrm{L}$ with an SRT of 16 days. The one possible reason is that SRT theoretically determines the microbial lifetime and microbial community. From our result, the shorter SRT may select microbial population with smaller COD consumption and PHB production ability compared with the longer SRT, this conclusion was in accord with literatures (Chen et al., 2016). Some a simulation SRT has been successful applied in $\mathrm{A}^{2} \mathrm{~N}$ process, and total effluent COD is always below $45 \mathrm{~g} / \mathrm{m}^{3}$, which satisfies the EC effluent standards (Hao et al., 2001). In addition, SRT could affect the PHB accumulation capability by sludge organic loading to biomass. In general, the SRT is proportional to biomass. But in this study, the concentration of COD and PHB in effluent with SRT of 22 days was similar to SRT of 16 days. This is probably because that the activated sludge with too long SRT contains aging microorganisms which might contribute to lower microbial activity. The growth of denitrifying polyphosphate accumulating organisms is inhibited with the too short or too long sludge retention time. 
Microorganisms absorbed carbon source and stored by polyhydroxybutyrate are related to SRT and organic loading. In this study, 16 days is the most suitable sludge retention time for denitrifying polyphosphate accumulating organisms.

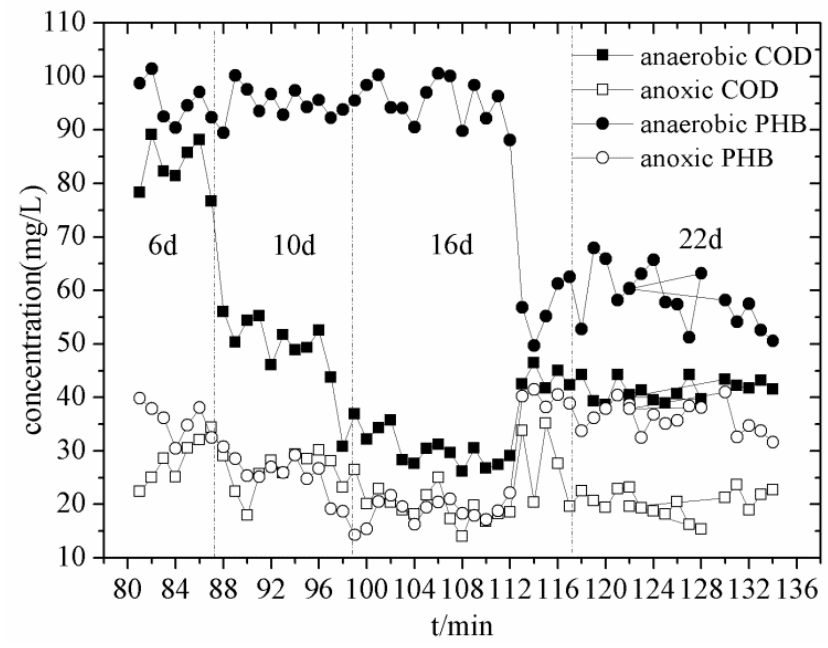

Figure 7. Effect of SRT on carbon removal

\section{Effect of SRT on sludge concentration and metabolism mechanism}

Activated sludge was the medium for microbial growth, results of SRT influence on mixed liquor suspended solid (MLSS), mixed liquor volatile suspended solid (MLVSS) and intracellular polymer content depicted in Table 1 indicated that SRT was positively correlated to MLSS and MLVSS (6, 10, 16, 22 days). In this study, the MLSS in the anaerobic condition with an SRT of 6 days was around $1860 \mathrm{mg} / \mathrm{L}$, and the value with a SRT of 22 days was around $4512 \mathrm{mg} / \mathrm{L}$, the poly-P content amount per unit of MLVSS decreased from 40.7 to $24.2 \mathrm{mg} / \mathrm{g}$ VSS. The higher MLVSS promoted a complete phosphorus release and a lower content of phosphorus in the anaerobic sludge, but variation of phosphorus content per unit amount of MLVSS was less than the MLVSS. The main reason is that organic loading reduce with MLVSS increase, and phosphorus release per unit amount of MLVSS decrease. Accordingly, anaerobic phosphorus release per unit amount of MLVSS was proportional to SRT in condition of SRT $\leq 16 \mathrm{~d}$ (MLVSS $\leq 2301 \mathrm{mg} / \mathrm{L}$ ), otherwise anaerobic phosphorus release per unit amount of MLVSS increased slightly with SRT enhancing in condition of SRT $>16 \mathrm{~d}$ (MLVSS $>2301 \mathrm{mg} / \mathrm{L})$. Acetic acid are taken up into the cell and stored as PHB, energy (ATP) is required for this process, which is generated by degradation of the internal storage products polyphosphate and glycogen. In this case, anaerobic poly-P release would partly affect PHB synthesis, otherwise, intracellular glycogen of denitrifying phosphorus accumulating organisms could decompose PHB. The anaerobic PHB synthesis per unit amount of MLVSS was the most $63.8 \mathrm{mg} / \mathrm{g}$ VSS with an SRT of 16 days, the SRT had a little effect on anaerobic PHB synthesis. In theory, the content of PHB improves with SRT increasing, but there was no obvious influence on anaerobic PHB synthesis per unit amount of MLVSS because of organic load increase.

In the anoxic period, the MLVSS increased from $1342 \mathrm{mg} / \mathrm{L}$ to $3203 \mathrm{mg} / \mathrm{L}$ while SRT was from 6 to 22 days. The poly-P content increased gradually during anoxic denitrifying phosphorus uptake with the SRT increasing from 6 to 16 days, however, 
these was a significant low at the point of SRT 22 days. Whereas SRT had less effect on anaerobic PHB production per unit amount of MLVSS in the reactor, it was because that MLVSS also increased with prolonged SRT, there was no significant difference in the amount of PHB synthesis of unit mass sludge. In the following electron acceptor phase, polyhydroxyalcanoates were degraded as electron for cell growth, polyphosphate synthesis. The system was slightly more effective in denitrifying phosphorus uptake at SRTs of 16 days than of 8, 10, 22 days, the PHB decomposition and polyphosphate accumulation were $16.3 \mathrm{mg} / \mathrm{g}$ VSS and $89.4 \mathrm{mg} / \mathrm{g}$ VSS at SRT of 16 days. PHB consumed more, phosphorus uptake more completely.

Table 1. Effect of SRT on MLSS, MLVSS, PHB and poly-P

\begin{tabular}{c|c|c|c|c|c|c|c|c}
\hline & \multicolumn{3}{|c|}{ anaerobic concentration } & \multicolumn{3}{c}{ anoxic concentration } \\
\hline $\begin{array}{c}\mathrm{t} \\
(\mathrm{d})\end{array}$ & $\begin{array}{c}\text { MLSS } \\
(\mathrm{mg} / \mathrm{L})\end{array}$ & $\begin{array}{c}\text { MLVSS } \\
(\mathrm{mg} / \mathrm{L})\end{array}$ & $\begin{array}{c}\text { PHB } \\
(\mathrm{mg} / \mathrm{g} \text { VSS })\end{array}$ & $\begin{array}{c}\text { poly-P } \\
(\mathrm{mg} / \mathrm{g} \text { VSS })\end{array}$ & $\begin{array}{c}\text { MLSS } \\
(\mathrm{mg} / \mathrm{L})\end{array}$ & $\begin{array}{c}\text { MLVSS } \\
(\mathrm{mg} / \mathrm{L})\end{array}$ & $\begin{array}{c}\text { PHB } \\
(\mathrm{mg} / \mathrm{g} \\
\text { VSS })\end{array}$ & $\begin{array}{c}\text { poly-P } \\
(\mathrm{mg} / \mathrm{g} \\
\text { VSS })\end{array}$ \\
\hline 6 & 1860 & 1380 & 55.7 & 40.7 & 1762 & 1342 & 35.9 & 58.3 \\
10 & 2760 & 1915 & 61.6 & 35.9 & 2610 & 1835 & 26.7 & 76.7 \\
16 & 3250 & 2301 & 63.8 & 23.1 & 3207 & 2237 & 16.3 & 89.4 \\
22 & 4512 & 3158 & 31.2 & 24.2 & 4607 & 3203 & 18.4 & 61.8 \\
\hline
\end{tabular}

\section{Conclusions}

In conclution, our investigation showed that $\mathrm{pH}$ and SRT as the main operational conditions to improve anaerobic organic matter degradation, PHB accumulation and anoxic nitrite nitrogen utilization, polyphosphate synthesis in anaerobic/anoxic activated sludge process. The optimal $\mathrm{pH}$ for denitrifying poly-phosphorus accumulating bacteria was 8 , the rate of anaerobic phosphorus release and anoxic phosphorus uptake was 20.95 and $23.29 \mathrm{mg} / \mathrm{g} \mathrm{VSS} / \mathrm{h}$. Activated sludge with the SRT of 16 days possessed better nitrite nitrogen utilization, organic matter degradation and phosphorus removal than sludge with the SRT of 6, 10 and 22 days. Although the $\mathrm{pH}$ and SRT could affect denitrifying phosphorus removal, the exct mechanism of action is still unknown. Therefore, futher research is needed to elucidate the exact mode of action of key factors on the activity of microorganisms in system.

Acknowledgements. This work was supported in part by the National Nature Science Foudation of China(No. 51776131 and 51678375).

\section{REFERENCES}

[1] Basset, N., Katsou, E., Frison, N., Malamis, S., Dosta, J., Fatone, F. (2016): Integratingthe selection of PHA storing biomass and nitrogen removal via nitrite in the main wastewater treatment line. - Bioresour. Technol. 200: 820-829.

[2] Bortone, G., Malaspina, F., Stante, L., Tilche, A. (1994): Biological nitrogen and phosphorus removal in ananaerobic/anoxic sequencing batch reactor with separated biofilm nitrification. - Water Sci. Technol. 30, 303-313.

[3] Cavaillé, L., Grousseau, E., Pocquet, M., Lepeuple, A. S., Uribelarrea, J. L., Guillermina, H. R., Paul, E. (2013): Polyhydroxybutyrate production by direct use of waste activated sludge in phosphorus-limited fed-batch culture. - Bioresour. Technol. 149: 301-309. 
[4] Chen, Z. Q., Huang, L., Wen, Q. X., Zhang, H. C., Guo, Z. R. (2016): Effect of sludge retention time, carbon and initial biomass concentration on selection process: From activated sludge to polyhydroxyalkanoate accumulating cultures. - J. Environ. Sci. doi: org/10.1016/j.jes.2016.03.014.

[5] GB 18918-2002. (2002): Discharge standard of pollutants for municipal wastewater treatment plant. - Chinese State Environmental Protection Administration, China.

[6] Ge, H. Q., Batstone, D. J., Keller, J. (2013): Operating aerobic wastewater treatment at very short sludge ages enables treatment and energy recovery through anaerobic sludge digestion. - Water Res. 47: 6546-6557.

[7] Ge, H. Q., Batstone, D. J., Keller, J. (2015): Biological phosphorus removal from abattoir wastewater at very short sludge ages mediated by novel PAO clade comamon adaceae. Water Res. 69: 173-182.

[8] Ge, Y., Wang, X. C., Dzakpasu, M. (2016): Characterizing phosphorus removal from polluted urban river water by steel slags in a vertical flow constructed wetland. - Water Sci.\& Technol. 73: 2644-2653.

[9] Hao, X. D., Van Loosdrecht, M. C. M., Meijer, S. C. F., Qian, Y. (2001): Model-based evaluation of two BNR processes - UCT and A2N. - Wat. Res. 35: 2851-2860.

[10] Hatamoto, M., Saito, Y., Dehama, K. (2015): Microbial community structure of a simultaneous nitrogen and phosphorus removal reactor following treatment in a UASBDHS system. - Water Sci. Technol. 71: 454-461.

[11] Jabari, P., Munz, G., Yuan, Q., Oleszkiewicz, J. A. (2016): Free nitrous acid inhibition of biological phosphorus removal in integrated fixed-film activated sludge (IFAS) system. Chem. Eng. J. 287: 38-46.

[12] Katsou, E., Malamis, S., Frison, N., Fatone, F. (2015): Coupling the treatment of low strength anaerobic effluent with fermented biowaste for nutrient removal via nitrite. $-\mathrm{J}$. Enviro. Manage. 149: 108-117.

[13] Kishida, N., Kim, J., Tsuneda, S., Sudo, R. (2006): Anaerobic/oxic/anoxic granular sludge process as an effective nutrient removal process utilizing denitrifying polyphosphate-accumulating organisms. - Water Res. 40: 2303-2310.

[14] Kuba, T., Smolders, G. J. F., Loosdrecht, M. C. M. V., Heijnen, J. J. (1993): Biological phosphorus removal from wastewater by anaerobic-anoxic sequencing batchreactor. Water \& Technol. 27: 241-252.

[15] Kuba, T., van Loosdrecht, M. C. M., Heijnen, J. J. (1996a): Phosphorus and nitrogen removal with minimal COD requirement by integration of nitrifying dephosphatation and nitrification in a two-sludge system. - Water Res. 30: 1702-1710.

[16] Kuba, T., Murnleitner, E., Loosdrecht, M. C. M. V., Heijnen, J. J. (1996b): A metabolic model for biological phosphorus removal by denitrifying organisms. - Biotechnol. Bioeng. 52: 685-695.

[17] Liu, H. B., Sun, L. P., Xia, S. Q. (2008): An efficient DPB utilization process: The modified A2N process. - Biochem. Eng. J. 38: 158-163.

[18] Liu, Y. L., Li, X., Kang, X. R., Yuan, Y. X. (2014): Performance of denitrifying phosphorus removal of Acinetobacteriastrain at low temperature. - Int. Biodeterior. Biodegrad. 95: 135-138.

[19] Liu, S. L., Li, J. Z. (2015): Accumulation and isolation of simultaneous denitrifying polyphosphate-accumulating organisms in an improved sequencing batch reactor system at low temperature. - Int. Biodeterior.\& Biodegrad. 100: 140-148.

[20] Lu, J. B., Yang, J. M., Xu, K., Hao, J., Li, Y. Y. (2016): Phosphorus release from coprecipitants formed during orthophosphate removal with $\mathrm{Fe}(\mathrm{III})$ salt coagulation: Effects of pH, Eh, temperature and aging time. - J. Environ. Chem. Eng. 4: 3322-3329.

[21] Luo, J. Y., Feng, L. Y., Zhang, W., Li, X., Chen, H., Wang, D. B., Chen, Y. G. (2014): Improved production of short-chain fatty acids from waste activated sludge driven by carbohydrate addition in continuous-flow reactors: Influence of SRT and temperature. Appl. Energy 113: 51-58. 
[22] Lv, X. M., Shao, M. F., Li, C. L., Li, J., Xia, X., Liu, D. Y. (2013): Bacterial diversity and community structure of denitrifying phosphorus removal sludge instrict anaerobic/anoxic systems operated with different carbon sources. - Res. Articale 89: $1842-1849$.

[23] Meinhold, J., Arnold, E., Isaacs, S. (1999): Effect of nitrite on anoxic phosphate uptake in biological phosphorus removal activated sludge. - Water Res. 33: 1871-1883.

[24] Mielcarek, A., Rodziewicz, J., Janczukowicz, W., Thornton, A. J., Jóźwiak, T., Szymczyk, P. (2015): Effect of the C:N:P ratio on the denitrifying dephosphatation in a sequencing batch biofilm reactor (SBBR). - J. Environ. Sci. 38: 119-125.

[25] Nittami, T., Oi, H., Matsumoto, K., Seviour, R. J. (2011): Influence of temperature, pH and dissolved oxygen concentration on enhanced biological phosphorus removal under strictly aerobic conditions. - New Biotechnol. 29: 2-8.

[26] Oehmen, A., Yuan, Z. G., Blackall, L. L., Keller, J. (2005): Comparison of acetate and propionate uptake by polyphosphate accumulating organisms and glycogen accumulating organisms. - Biotechnol. Bioeng. 91: 162-168.

[27] Oehmen, A., Vives, M. T., Lu, H., Yuan, Z., Keller, J. (2005): The effect of pH on the competition between polyphosphate accumulating organisms and glycogen accumulating organisms. - Water Res. 39: 3727-3737.

[28] Oehmen, A., Saunder, A. M., Vives, M. T., Yuan, Z., Keller, J. (2006): Competition between polyphosphate and glycogen accumulating organisms in enhanced biological phosphorus removal systems with acetate and propionate as carbon source. - J. Biotechnol. 123: 22-32.

[29] Peng, Y. Z., Li, Y. Z., Wang, S. Y., Wang, Y. Y. (2004): Denitrification and dephosphatation by anaerobic/anoxic sequencing batch reactor. - Chinese J. Chem. Eng. 12: 877-880.

[30] Reza, M., Cuenca, M. A. (2016): Simultaneous biological removal of nitrogen and phosphorus in a vertical bioreactor. - J. Environ. Chem. Eng. 4: 130-136.

[31] Smolders, G. J. F., Meij, J. V. D., Loosdrecht, M. C. M. V., Heijnen, J. J. (1994): Model of the anaerobic metabolism of the biological phosphorus removal process: stoichiometry and $\mathrm{pH}$ influence. - Biotechnol. Bioeng. 43: 461-470.

[32] Sun, L., Zhao, X. X., Zhang, H. F., Zhang, Y. Q. (2015): Biological characteristics of a denitrifying phosphorus-accumulating bacterium. - Ecol. Eng. 81: 82-88.

[33] Tayà, C., Garlapati, V. K., Guisasola, A., Baeza, J. A. (2013): The selective role of nitrite in the PAO/GAO competition. - Chemosphere 93: 612-618.

[34] Wang, Y. Y., Zhou, S., Wang, H., Ye, L., Qin, J., Lin, X. M. (2015a): Comparison of endogenous metabolism during long-term anaerobic starvation of nitrite/ nitrate cultivated denitrifying phosphorus removal sludge. - Water Res. 68: 374-386.

[35] Wang, X. X., Wang, S. Y., Xue, T. L., Li, B. K., Dai, X., Peng, Y. Z. (2015b): Treating low carbon/nitrogen $(\mathrm{C} / \mathrm{N})$ wastewater in simultaneous nitrification-endogenous denitrification and phosphorous removal (SNDPR) systems by strengthening anaerobic intracellular carbon storage. - Biochem. Eng. J. 77: 147-153.

[36] Wong, P. Y., Ginige, M. P., Kaksonen, A. H. (2015): Simultaneous phosphorus uptake and denitrification by EBPR-r biofilm under aerobic conditions: effect of dissolved oxygen. - Water Sci. Technol. 72: 1147-1154.

[37] Zeng, R. J., Saunders, A. M., Yuan, Z. G., Blackall, L. L., Keller, J. (2003): Identification and Comparison of Aerobic and denitrifying polyphosphate-accumulating organisms. Biotechnol. Bioeng. 83: 140-148.

[38] Zhang, H. L., Sheng, G. P., Fang, W., Wang, Y. P., Fang, C. Y., Shao, L. M., Yu, H. Q. (2015): Calcium effect on the metabolic pathway of phosphorus accumulating organisms in enhanced biological phosphorus removal systems. - Water Res. 84: 171-180.

[39] Zhao, W. H., Zhang, Y., Lv, D. M., Wang, M. X., Peng, Y. Z., Li, B. K. (2016): Advanced nitrogen and phosphorus removal in the pre-denitrification 
anaerobic/anoxic/aerobic nitrification sequence batch reactor (pre-A2NSBR) treating low carbon/nitrogen (C/N) wastewater. - Chem. Eng. J. 302: 296-304.

[40] Zhou, Y., Oehmen, A., Lim, M., Vadivelu, V., Ng, W. J. (2011): The role of nitrite and free nitrous acid (FNA) in wastewater treatment plants. - Water Res. 45: 4672-4682. 